究が水道の水質保全に多大の貢献をさ机て打り，この ことについて高く評価し，また敵意を表するところで
あるが，今後とも一層の発展を期されることを願らも のである。

\title{
協会は水質污濁研究の澪 標に*
}

中本至

\section{1. 水質污濁問題の多様化時代}

わが国の水質污濁問題も昭和 $30 \sim 40$ 年代の状況に比 較すれば著しく改善されてきている。例光ば,「環境白 書」に打いても, 公共用水域の環境基準の達成状況は, 水銀, カドミウム等のいわゆる人の健康にかかわる有 害物質項目については, ほとんど100\%に近い達成率と なっているし，また， BOD， COD 等の生活環境項目に ついても, 湖沼, 内湾等の閉鎖性の強い水域を除いて は, 着実に達成率は向上している。

これには，昭和 45 年に制定された「水質污濁防止法」 による工場等の事業場に対する排水規制及び昭和 38 年 以降 5 次にわたる五箇年計画によって整備が進められ てきた下水道（昭和 38 年度の普及率 $7 \%$, 昭和 59 年度 末の普及率 $34 \%$ ）などの種々の施策が大きく寄与して いるのではないかと思われる。

しかし，新たな問題も顕在化しつつあるし，また， 将来問題となってくる恐れのあるものもある。

例えば, 湖沼や内湾の水質改善が, 多くの関係者の 努力によって効果をあげているものの，なかなか所期 の目的（環境基準の達成）に到達していないものが多 い。さらに, 富栄養化によるアオコ発生現象などの深 刻化など新たな問題を生じている。この問題について は，一定の業種，規模以上の事業場の排出水を規制す る「水質污濁防止法」による施策や下水道の完全整備

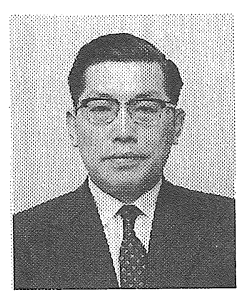

Itaru Nakamoto

昭和 45 年 建設省都市局下水道課長補 佐

56 年 同省同局公共下水道課長

59 年 同省同局下水道部長

* A Guidepost for Study, 昭和 60 年12月 5 日受理

だけでは解決できないと考学られる。（図 1）

わが国のよらに, 高密度の人間の活動が行われてい る湖沼については, 自然污濁, 農畜産業, 不特定污濁 源など污濁源も広範で，それらの占める割合も多いの で, 湖沼の流域全体の水循環, 物質 (污濁に寄与する) 循環をはっきりとらえた対策を講じない限り, 抜本的 な解決は不可能である。

しかも, これらの対策は, 施策とその効果が定量的 に関係づけられた説得性のあるものでなければ，関係 する多くの人々の協力を得ることはできず, 実施不可 能という事態に陥ってしまうのである。

その他, 大きな課題として有機塩素化合物などの有 害化学物質による水質污染, 重要な水資源の 1 つであ る地下水質の污染など解決を図るべき問題, さらには 酸性雨等の地球的規模の污染問題もある。このように, 水質污濁の課題は空間的にも質的にも大きな広がりを 見せ，多様化している時代に入ったのである。

\section{2. 水質污濁研究に望むもの}

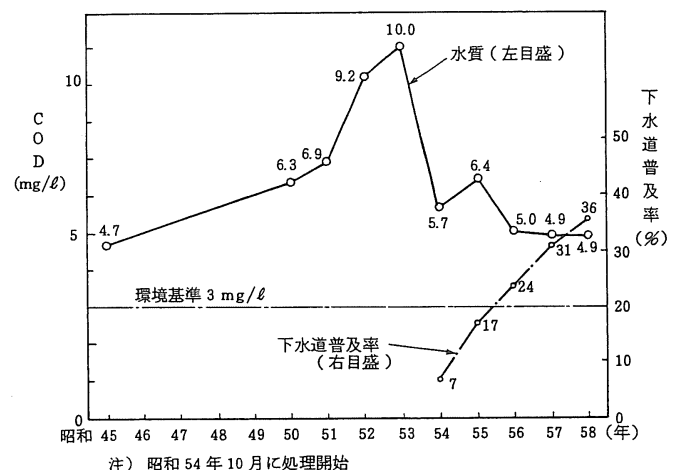

水質の改善状況（長野県諏訪湖）

諏訪湖の水質はアオコの発生に代表されるように著しく悪 化していたが, 下水道の整備等によって, 水泳大会が復活す るなど, 大幅に改善されてきている。しかし，下水道が完備 されても, 湖に流入する污濁源が多岐にわたるため環境基 準の達成は極めて難しいと考えられる。 
水質に関する研究は，人の健康とか生活に直接係り のある “水”を相手にしているだけに，その污濁メカ ニズムが自然現象でありながら, 自然科学の分野では 極めて人間的な内容をもつものである。

従って, 研究の対象も自然の注か, 人, 社会と極め て広く，かつ，水だけでなく大気，土壤などの関わり もある。しかし, 研究対象があまりにも広いことから, ややもすれば，せっかくの研究が発散してしまい，役 に立たないといら落とし穴に落ちてしまう恐れがあ る。

本来, 研究成果は社会に広く還元され利用されるべ きものである。この場合, 他の一般の科学と異なるの は, その成果が商品化されて, 直接市場へ流れたり, 新たな市場を形成するといらことが少ない性格のもの ではないだろらか。水環境を質的に向上させるための， 総合的な施策の 1 つとして, 研究の成果が生かされて いくもののように思える。

そこで, 研究のテーマ, 内容は, その時代のニーズ に合致したものであり, 全体の流れのなかでの位置つ けがはっきりしている必要があろら。つまり, 枝葉末 節的なものでなく, 流れの本流にあり, ことの是非が 判断できるものを提供するよらな内容であって葟し w。

下水道に係る分野を例にして，この点を具体的に述 べてみる。従来は，「下水処理」とか「污泥処理」とい ら大きな分類のなかで，それぞれ効率化を図るといら 研究が主体であったが, 水循環, 物質循環のなかで下 水道をみるべきであるといら視点に立って，土木研究 所等の機関では「下水道の水質保全に打ける効果」「湖 沼に扣ける下水道の役割」などをできるだけ定量的に 把握し, 単に下水道施設の効率化を求めるだけでなく 常に下水道の位置つけを明確にする心掛けをもつよう にしているつもりである。

また, 「下水処理」「污泥処理」に打いても, 単に従 来の手法を推し進めるだけでなく，近年，目覚ましい 成果をあげつつある先端技術を活用した研究を進める ことによって, 研究の活性化と内容の革新を図ってい る。特に, 下水処理は従来から微生物を上手に利用し たシステムであるが，この技術にバイオテクノロジー を導入することによって処理技術をさらに洗練化しよ らとする目的で, 昭和 60 年度から「バイオフォーカス $\mathrm{WT}$ といらプロジェクトにとりかかっている。
いずれにしても, 下水道は人の活動によって生じる 下水を環境が受容する形まで処理するものであるの で, 自然科学の問題だけでなく, 文化, 社会, 経済な ど広い分野にわたるものであり，人々の同意を得なが ら整備を着実に実施して，確実に効果をあげなければ ならない。従って, 関係する研究成果は, わかりやす く, 定量的であり, 説得性のあるものでなければなら ない。例えば，処理水だけを細かく分析して，ある有 害物質が含まれているから，下水処理は問題が大きい といら単純な結論に結びつけるのではなく, 人の活動 を通して自然的に社会的に，これだけ発生し，下水道 へはこれだけ,下水道以外の系にはこれだけ流出する, 下水道へ流入したものは, その処理過程で, どの程度 削減されているかといったように，総合的に分析する 必要があろら。そして，さらに問題があれば，全体的 な解決を図っていく必要があると考光る。そして，こ の場合，施策を確実に実行するためには技術，エネル ギー，費用等の制約条件についても考光て抏くことが 研究の前提として重要なことだと考劣る。

\section{3。協会は研究のニーズ情報を}

水質污濁に関する課題が大きく変化してきているこ とは先に述べたが，今後も，大きく変化していくこと は想像に難くない。そして，これを解決していくため には, 解明すべき研究課題が山積している。

一方, 水質污濁問題への取り組みの本格化に伴って, 研究者の数も著しく増えてきて扣り, またその構成(専 門) 分野も多様化し, 研究のポテンシャルは飛躍的に 大きくなってきている。牤そらく，このように充実し た研究者群は，世界でも完全にトップレベルにあるの ではないかと思われる。

このよらな状況において, 本協会が水質污濁問題の 本質を常に示し続けていけば，わが国の水質污濁に関 する研究の水準はさらに向上し, 維持していくことが でさるのではないだろらか。つまり, 協会が研究の“道 しるべ”“み拈つくし”の役割を務めていただくことを 期待したい。そのためには, 研究のニーズが何かとい ら情報を整理し，会員に示していくことが重要なので はないだろらかと考える。

最後に, 大勢の優秀な若い研究者が水質污濁研究に, 新たに飛び込んでくるよらな鬽力ある分野に育ててい ただくことを協会に期待したい。 